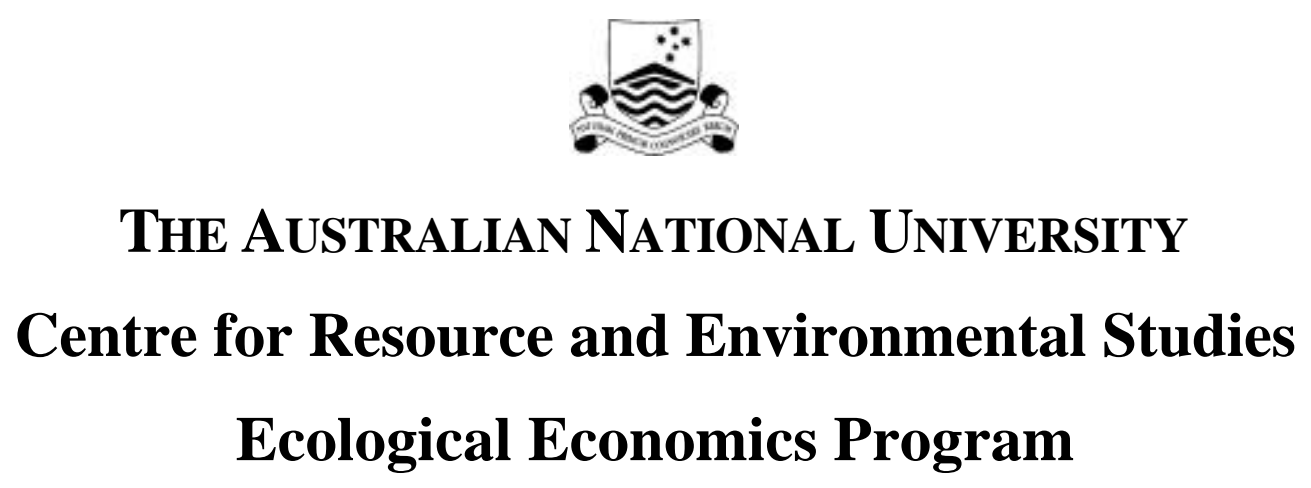

Working Papers in Ecological Economics

N umber 9804

M ay 1998

IS THERE AN ENVIRONMENTAL KUZNETS CURVE FOR SULFUR? by

David I. Stern, Tony Auld, Mick S. Common, and Kali K. Sanyal

CRES, ANU, Canberra ACT 0200, AUSTRALIA

Tel: +61262494277

Fax: +61262490757

E-Mail: dstern@cres.anu.edu.au

WWW: http:/ / cres.anu.edu.au/ 〜dstern/ anzsee/ EEP.html 
The Ecological Economics Program (EEP) was established in CRES as the result of a successful application to the Institute of Advanced Studies 1994 Strategic Initiatives round. EEP's objective is to promote the development of ecological economics by conducting research and acting as a focal point for ecological economics activities in the Canberra region. To this end, EEP:

- hosts the office of ANZSEE, the Australia New Zealand Society for Ecological Economics

- runs a seminar series

- $\quad$ runs a working paper series on the World Wide Web

- can serve as a host for individuals wishing to do ecological economics research as visitors to the ANU (Contact Mick Common for more information).

- $\quad$ supervises research students. People interested in doing a research degree in ecological economics should contact Mick Common or David Stern for more information.

The working paper series reports on research conducted in EEP by academic staff, visitors, and students, and invited seminar presenters. 


\section{Working Papers in Ecological Economics}

9601 David Stern. Progress on the environmental Kuznets curve?

9701 Michael Young. Water rights: an ecological economics perspective.

9702 David Stern and Robert Kaufmann. Time series properties of global climate variables: detection and attribution of climate change.

9703 Ken Menz and Katie Ellis. Fire as an economic disincentive to smallholder rubber planting in Imperata areas.

9704 Roger Attwater. Property entitlements and land reform in upland Thai catchments.

9705 Mick Common, Tim Bull, and Natalie Stoeckl. The travel cost method: an empirical investigation of Randall's difficulty.

9706 Colin Hunt. Economic instruments for environmental and natural resource conservation and management in the South Pacific.

9707 David Alden. Recreational user management of parks: an ecological economic framework.

9708 David Stern and Robert Kaufmann. Is there a global warming signal in hemispheric temperature series?

9801 Daniel McKenney. Resource economists should do more cost analysis and less benefit analysis.

9802 Roy Darwin. FARM: A global framework for integrated land use/cover modeling.

9803 David Stern. A multivariate cointegration analysis of the role of energy in the U.S. macroeconomy

9804 David Stern, Tony Auld, Mick Common, Kali Sanyal. Is there an environmental Kuznets curve for sulfur? 


\title{
Is There an Environmental Kuznets Curve for Sulfur?
}

\author{
David I. Stern*, Tony Auld, Michael S. Common, Kali K. Sanyal \\ Centre for Resource and Environmental Studies, The Australian National University, \\ Canberra ACT 0200, Australia.
}

Paper presented at the World Congress on Environmental Economics, Venezia, Italy, June 1998.

* Corresponding author: Tel: +61 26249 0664, Fax: +61 262490757 , E-Mail: dstern@cres.anu.edu.au 


\begin{abstract}
The environmental Kuznets curve (EKC) hypothesis proposes that there is an inverted U-shape relation between environmental degradation and income per capita. Various explanations for this phenomenon have been put forward and some authors argue that important explanatory variables are omitted from conventional EKC estimates. Inclusion of these omitted variables is argued to increase the estimated "turning point" - the level of GDP per capita above which environmental degradation is declining. In this paper we use a new cross-section/time-series data base of sulfur emissions for a wide range of developed and developing countries. The methodology involves estimating EKCs for subsets of this database as well as for the sample as a whole. The results show that estimating an EKC using data for only the OECD countries, as has often been the case, leads to estimates where the turning point is at a much lower level than when the EKC is estimated using data for the World as a whole. The paper explores possible explanations of these results using Monte Carlo analysis, and other statistical tests.We conclude that the simple EKC model is fundamentally misspecified and that there are omitted variables which are correlated with GDP.
\end{abstract}

\title{
Acknowledgements
}

We thank Muhammed Akmal for useful comments. 


\section{Is There an Environmental Kuznets Curve for}

\section{Sulfur?}

\section{Introduction}

The environmental Kuznets curve (EKC) hypothesis proposes that there is an inverted U-shape relation between various indicators of environmental degradation and income per capita. A number of theoretical explanations for this relationship have been put forward (e.g. Pezzey, 1989; Lopez, 1994; Selden and Song, 1995) but not empirically tested. Recently, a number of empirical studies have examined whether particular additional variables are responsible for the EKC relationship (Stern, 1998). These researchers either argue that income and income squared are merely proxies for the true underlying variables or that additional explanatory power is contributed by the additional variables. However, there has been little systematic effort to test whether the basic EKC model is adequately specified. The finding that a specific variable helps explain the pattern of emissions or concentrations is subject to potential omitted variables bias. The number of diagnostic statistics used in EKC studies has increased over time (Stern, 1998). But the results of these tests have only been used to select estimators and not to question whether the basic EKC model is correctly specified.

A recent paper by Dijkgraaf and Vollebergh (1998) represents a departure from this trend. The study estimates EKCs for carbon emissions for a panel data set of OECD countries and individual time series for each of the countries in the panel. The authors find that the coefficients in the individual time series regressions vary widely. They found linear, inverted-U shaped, $U$ shaped, and cubic EKCs in the individual countries vs. an inverted $U$ in the sample as a whole. They also found that in only some countries were the residuals serially correlated while the panel estimate had serially correlated residuals. The conclusion is that there is not a meaningful EKC for carbon emissions while there are some meaningful relations between income and emissions in individual countries.

The majority of EKC studies, with the exception of carbon emissions studies, are estimated using emissions data for some or most OECD countries or concentrations data for a variety of cities primarily in developed countries. These regressions typically show turning points - i.e. the level of income above which pollution declines - well within the sample. Interestingly, estimated turning points for carbon EKCs are usually far above the maximum GDP in the sample. The usual explanation for this is that carbon does not have local pollution impacts and has therefore not been regulated, while emissions such as sulfur have obvious and more localized impacts and have been subject to regulation (Shafik, 1994). But the Dijkgraaf and Vollebergh (1998) EKC (estimated with 
fixed time and country effects), which is limited to OECD countries, has a turning point at $54 \%$ of maximal GDP in the sample.

It is possible, that due to omitted variables, turning point estimates from regressions using only developed country data may be biased downwards - assuming that there is an EKC relationship of some sort. ${ }^{1}$ For example, trade specialization may be a significant factor in explaining the differences in emissions among countries (Stern et al., 1996). Developed countries will tend to be specialized towards the production of capital and knowledge intensive goods while developing countries will tend to be specialized towards the production of labor and resource intensive goods. Ceteris paribus, emissions will be lower in developed countries and higher in developing countries. However, this is not an EKC type relation, because as economic growth proceeds though some countries might "outsource" their pollution to other countries, some countries must still be specialized towards resource intensive production. If pollution is being reduced in some countries by this type of "shell game" then eventually there will be no countries to which polluting production can be redirected. If this is the case, then the EKC is an illusion as regards its implications for the development of the world economy (Stern et al., 1996). In this type of world, estimation of an EKC using just developed country data will suggest that pollution reduction is easier than it is in fact for the World as a whole.

Sulfur emissions and concentrations are one variable for which there is evidence from a number of authors on the existence of an inverted U-shape EKC (e.g. Grossman and Krueger, 1995; Shafik, 1994; Panayotou, 1995; Selden and Song, 1994). Therefore it is of particular interest to examine this variable in a study of the possible downwards bias of existing estimates. Also, simultaneity issues (Stern et al., 1996) will be less important than they might be for energy, $\mathrm{CO}_{2}$, or deforestation EKCs (Stern, 1998). In principle, sulfur can be removed using "end of pipe" technologies. Also, substitution away from coal or high-sulfur coal is far easier than substitution away from fossil fuels in general. Therefore, changes in sulfur emissions are less likely to drive GDP growth than are changes in energy use, $\mathrm{CO}_{2}$ emissions etc.

In this paper we make use of a new data set on sulfur emissions (A.S.L. and Associates, 1997). This database includes emissions of sulfur from burning hard coal, brown coal, and petroleum, and sulfur emissions from mining and smelting activities for most of the countries of the world from 1850 to 1990. Estimated emissions are based on the use of these fuels and the level of mining activity, estimated sulfur content and estimated sulfur retention or removal from waste streams. These data have been compiled due to the strong interest in the role of sulfur emissions in affecting global

\footnotetext{
${ }^{1}$ Panayotou (1993) uses data for a large number of countries to estimate a sulfur EKC. However, this turning point estimate is biased downwards because of use of ordinary exchange rates in place of PPP data and a crosssection dataset in place of a panel dataset .
} 
temperatures, primarily in the northern hemisphere, in the last century and a half (Mitchell et al., 1995; Santer et al., 1996b; Kaufmann and Stern, 1997). Previous time series (e.g. Dignon and Hameed, 1989; Hameed and Dignon, 1992; Kato, 1996; Stern and Kaufmann, 1996) were not available at this resolution either temporally or spatially or were confined to certain countries and regions (e.g. OECD, 1994; US EPA, 1995). Previous EKC analyses of sulfur have used either ambient concentrations (e.g. Grossman and Krueger, 1995; Shafik, 1994), cross sectional emissions estimates (Panoyotou, 1993), or data from mainly OECD countries in the 1970s and 1980s (Selden and Song, 1994). Our global EKC estimates use data for all countries that have a full set of sulfur and GDP per capita data (from the Penn World Table) for 1960-90. There are 74 such countries. The list of countries is in the Appendix. The countries include around $81 \%$ of the world population in 1990 .

The next section of the paper reviews the literature on sulfur EKCs with particular attention to estimated turning points. Subsequent sections investigate potential bias using regressions for the world as a whole, OECD, and non-OECD samples, Monte Carlo analyses, and time series regressions for individual countries.

\section{Literature Review of Sulfur EKCs}

A number of authors have estimated environmental Kuznets curves for sulfur (Cole et al., 1997; de Bruyn, 1997; de Bruyn et al., 1998; Grossman and Krueger, 1991; Kaufmann et al., 1998; Panayotou, 1993, 1995, 1997; Selden and Song, 1994; Shafik, 1994; Shafik and Bandyopadhyay, 1992; Shukla and Parikh, 1992; Torras and Boyce, 1996; Vincent, 1997). In this section, we review the various estimates. The results are summarized in terms of turning points. Stern et al. (1996) argued that higher turning points are found for regressions using purchasing power parity exchange rates and emissions relative to regressions using market exchange rates and ambient concentrations. These factors need to be controlled for when we examine the impact on the estimated turning point of different temporal and geographical samples and additional explanatory variables. Therefore, we pay particular attention to the countries and time periods in each sample, whether sulfur is measured in terms of emissions or in terms of ambient concentrations, whether GDP is measured in ordinary exchange rates or in purchasing power parity terms, and which additional explanatory variables (besides GDP and GDP squared) are included in the model. These attributes are summarized in Table 1. Other attributes are listed in Stern (1998).

It is not possible to calculate relevant turning points for all the studies listed above. For example, some of the studies do not use a conventional quadratic or cubic specification (e.g. de Bruyn et al., 1998). The majority of the remaining studies use concentrations data, usually based on the GEMS database. This database comprises ambient measurements from a variety of sites in various cities in many countries during different periods of time. All estimates of the turning point using concentration 
data are less than $\$ 5000$ with the exception of the Kaufmann et al. (1998) estimate. Kaufmann et al. (1998) used an unusual specification which includes GDP per area and GDP per area squared variables. Of the emissions based estimates Panayotou (1993) estimates the lowest turning point \$2894. However, his single cross-section of data was based on the consumption of different fuels under the assumption that emissions coefficients are the same in all countries. Also, he measured income using market exchange rates resulting in a lower turning point ceteris paribus. Both Selden and Song (1994) and Cole et al. (1997) use databases that are dominated by, or consist solely of, emissions from OECD countries. Their estimated turning points are $\$ 6000$ and $\$ 8700$ respectively.

All these turning points are far lower than our estimate reported in the last row of the table and discussed in the next section of the paper.

\section{Global, OECD, and non-OECD EKC Estimates}

\section{a. Data and Econometric Methods}

The data are described above and in the Appendix. An additional point of interest is that ASL's estimated emissions for many developed countries, such as West Germany, Canada, Sweden, and Japan, differ substantially from the better known OECD estimates. UK and US data are similar in both databases. OECD estimates for the former group of countries tend to overestimate emissions in the early 1970s and underestimate emissions in the late 1980s and the 1990s relative to the ASL data. The ASL data show much smaller reductions in emissions over time for these countries. In the case of Sweden emissions rise over time instead of declining. Also Vincent (1997) shows a steep decline in Malaysian emissions between 1988 and 1989 due to a switch to gas-fired electricity generation. The ASL data show a big increases in emissions from coal burning at exactly the same point in time. The complete dataset of 2294 observations is presented in Figure 1. Generally emissions rise with income though there is some sign of a decline at high income levels. The outliers at the upper right are Kuwait which had both very high income and emissions in the 1960s. Omitting Kuwait from the sample does not significantly alter the results reported in this paper.

We estimate a logarithmic quadratic EKC for World, OECD, and non-OECD samples. We use both fixed effects and random effects models with both country and time effects. Both dependent (emissions per capita) and independent (PPP GDP per capita) variables are in natural logarithms. The model is given by:

$\ln (\mathrm{S} / \mathrm{P})_{\mathrm{it}} \quad=\quad \alpha_{\mathrm{i}}+\gamma_{\mathrm{t}}+\beta_{1} \ln (\mathrm{GDP} / \mathrm{P})_{\mathrm{it}}+\beta_{2}(\ln (\mathrm{GDP} / \mathrm{P}))_{\mathrm{it}}^{2}+\varepsilon_{\mathrm{it}}$

where $S$ is sulfur emissions in tonnes of sulfur, $\mathrm{P}$ is population, $\varepsilon$ is a random error term, the $\alpha_{i}$ are country specific intercepts, the $\gamma_{t}$ are time specific intercepts, and the countries are indexed by $i$ and 
the time periods by $\mathrm{t}$. The time specific intercepts should account for some time varying omitted variables and stochastic shocks that are common to all countries. They may help reduce the degree of serial correlation in the remaining residual. The turning point level of income is calculated by $\tau=$ $\exp \left(-\beta_{1} /\left(2 \beta_{2}\right)\right)$.

The fixed effects model treats the $\alpha_{\mathrm{i}}$ and $\gamma_{\mathrm{t}}$ as regression parameters. In practice, the means of each variable for each country are subtracted from the data for that country and the mean for all countries in the sample in each individual time period is also deducted from the observations for that period. Then OLS is used to estimate the regression with the transformed data. The random effects model treats the $\alpha_{i}$ and $\gamma_{t}$ as components of the random disturbance. The residuals from an OLS estimate of the model with a single intercept are decomposed and used to transform the variables. More details are provided by Hsiao (1986).

If there is correlation between the effects $\alpha_{i}$ and $\gamma_{t}$ and the explanatory variables then the random effects model cannot be estimated consistently (Mundlak, 1978; Hsiao, 1986). Only the fixed effects model can be estimated consistently. The extent of such bias in the random effects estimate can be tested using a Hausman (1978) test. This test compares the slope parameters estimated for fixed effects and random effects models. A significant difference indicates that the random effects model is estimated inconsistently. It is our contention that omitted variables will be accounted for by the country and time effects in the model. Therefore the Hausman test can be used as an indication of bias due to omitted variables. To make sure of this interpretation we also use Monte Carlo analysis (section 3c.) and individual country regressions (section 4.).

\section{b. $\quad$ Econometric Results}

The results are presented in Table 2. First we examine the results for the World as a whole. This EKC has an inverted $\mathrm{U}$ shape for both random and fixed effects formulations. Adjusted $\mathrm{R}^{2}$ is not comparable for the fixed effects and random effects models as the dependent variable is transformed differently in the two cases. The Hausman test indicates that the effects are correlated with the explanatory variables so that the random effects model cannot be estimated consistently. Both models (fixed and random effects) show strong serial correlation. This too is an indication of serious misspecification. The Durbin Watson test can also be used as a cointegration test (Engle and Granger, 1987). The critical value at the $5 \%$ level is 0.35 . The World model residuals are just on the borderline between cointegration and non-cointegration. Lack of cointegration indicates that integrated (random walk or I(1)) variables that are necessary to provide an adequate model of the data are omitted or possibly that irrelevant integrated variables have been included in the model.

The time effects show a decline in emissions ceteris paribus (Figure 2). The average rate of decline is $1.5 \%$ per annum. These time effects do not point to sudden declines associated with events such 
as the oil price shocks and the LRTAP protocols of the 1980s in Europe, but instead to more subtle variations imposed on a long run decline. The implied turning point is very high by the standards of the existing literature - $\$ 78703$.

These results suggest two propositions:

1. When data for a large number of developing countries are included in the EKC a much higher turning point results than in previous studies that use just OECD data. Essentially the global EKC is monotonic as the estimated turning point is far above all countries' income levels except 1960s Kuwait. This result is in line with results for carbon emissions (Dijkgraaf and Vollebergh, 1998). We will test this hypothesis by estimating regressions for OECD and non-OECD subsamples of the data. Also the Hausman test indicates that there may be omitted variables correlated with the country effects. This suggests a potential role for variables that have different values in different countries - for example the effects of trade specialization on the EKC relationship. The possible importance of trade effects is suggested by the high turning point. When we estimate an EKC using an almost complete global data set the possibility of declining global emissions through increases in income alone appears to be an illusion.

2. The time effects (Figure 2) result in the extraction of a stochastic time trend or signal from the data. The fluctuations around this trend may be related to the business cycle as suggested by de Bruyn et al. (1998). But the results do not point to a major role for energy prices in producing EKC type behavior as hypothesized by Moomaw and Unruh (1997), Unruh and Moomaw (1998) and de Bruyn et al. (1998). The decline in emissions had set in before 1973. On the other hand, the serial correlation tests show that there are time-dependent variables that are not accommodated by this single global stochastic time trend. There may be variables with different serially correlated or integrated trends in different countries.

These propositions are further examined in the remainder of the paper. The first investigation is the estimation of an EKC for the 23 OECD countries alone. In this case the random effects estimator is consistent - variations in country effects among the OECD countries are not correlated with the income variables. There is however, severe serial correlation and a lack of cointegration. There clearly could therefore be omitted integrated variables. The time effects (Figure 2) do show a sharp decline in the mid-1980s but emissions have tended to increase again, ceteris paribus. The overall rate of decline is very low. Again the EKC has the inverted-U shape. The turning point is very much lower than for the global model: \$9201. This turning point is well within sample. This result is in line with previous studies such as Selden and Song (1994) and shows that differences between our data and OECD data are not the reason for the very high estimate of the global turning point. 
The 51 non-OECD countries dominate the sample and so their results are mostly similar to those for the World as a whole. As in the case of the World model, the random effects model cannot be consistently for the non-OECD countries. The estimated turning point is extremely high - \$131867 almost double the turning point for the global sample. The EKC is therefore monotonic for the nonOECD countries. The estimated time effects (Figure 2) are very similar to those estimated for the global sample. Emissions decline strongly over time though emissions increase strongly with rising income levels. Serial correlation is very strong but marginally less severe than for the global model.

The adjusted $\mathrm{R}^{2}$ statistics can be compared across the three subsamples. The coefficient of determination is greater in the OECD subsample than in the World sample but slightly lower in the non-OECD subsample than in the sample as a whole. An F test can be calculated for both the random effects and fixed effects models and is reported in Table 2. As the random effects model is not consistently estimated the Chow test for the fixed effects model is most relevant. The null hypothesis that there is a single world EKC model can be easily rejected at $5 \%$ or $2 \%$ levels but not at a $1 \%$ level of significance.

As the estimated residuals show a very high degree of serial correlation we also estimated models using first differences (Table 3):

$$
\Delta \ln (\mathrm{S} / \mathrm{P})_{\mathrm{it}} \quad=\quad \alpha+\beta_{1} \Delta \ln (\mathrm{GDP} / \mathrm{P})_{\mathrm{it}}+\beta_{2} \Delta\left[(\ln (\mathrm{GDP} / \mathrm{P}))^{2}\right]_{\mathrm{it}}+\varepsilon_{\mathrm{it}}
$$

In this case the constant represents the mean rate of technical progress. The goodness of fit of these models is, as expected, far lower than for the levels models but the OECD estimates are totally statistically insignificant. The coefficients for the non-OECD and World models are significant at the $10 \%$ level and above. These models exhibit moderate positive serial correlation. The rates of technical change in the first difference results are about twice as great as in the levels results. The turning points are less extreme than for the levels estimates but the non-OECD and World turning points are still above the incomes levels of all countries except 1960s Kuwait while the OECD turning point is well within sample. 


\section{c. $\quad$ Monte Carlo Analyses}

Further insight can be gained from a Monte Carlo study that assumes that the data generating process is a single global EKC. The differences between the estimated parameters using this artificial data and the parameters estimated using real data can throw further light on the reasons why the global EKC model fails.

We generated data for four alternative artificial models: a model with different country and time intercepts, a model with just different intercepts for each country, a model with just different intercepts for each time period, and a model with a single global intercept. In each case we used the global fixed effects parameter estimates and actual observations on GDP per capita to generate the deterministic part of the model. Note that the estimated fixed country effects have, by construction, ${ }^{2}$ a very low correlation with the GDP variables: .05693 and .06458 with $\ln (\mathrm{GDP} / \mathrm{P})$ and $\ln (\mathrm{GDP} / \mathrm{P})^{2}$. The time effects have a stronger correlation with the untransformed income variables: -0.189559 and -0.190732 respectively. Thus, at least in the case of the country fixed effects the difference between the turning points in the simulation and in the data reflects in part the effect of correlation between the true effects and the income variables.

To the deterministic part we added normally distributed random errors with the same standard deviation as the estimated residuals in the global model. In each case we generated 500 data sets of 2294 observations each. We estimated 3 regressions with each data set - World, OECD, and nonOECD, using each of the two methods - fixed effects and random effects. In total we estimated 12000 regressions. The results are presented in Table 4 in terms of median estimated turning points. This statistic is chosen because of the presence of a few outliers in each model's set of results.

The model that best reproduces the data is the country and time intercepts model. The random effects estimates show a substantially lower turning point for the OECD countries, and a slightly higher turning point for the non-OECD countries relative to the World as a whole. The fixed effects estimate shows less variation among the subsamples but the OECD subsample still exhibits a lower turning point. The time intercepts only model also shows a substantially depressed turning point estimate for the OECD using the random effects model but differences across subsamples are smaller. The other two intercept treatments show far less inconsistency and more equal turning points across samples.

These results show that even when a single stochastic time trend is forced on the World as a whole but different intercepts, which are uncorrelated with GDP, are allowed in different countries differences emerge between the turning point estimates in the subsamples. But these differences are

\footnotetext{
2 The country effects are orthogonal to the transformed GDP variables used in the fixed effects regression.
} 
smaller than in the true data. This shows that the correlation between the true country effects and GDP and differences between the true time trends and the true income parameters across countries account for most but not all of the lower turning point in the OECD and higher turning point in the rest of the World.

The explanation for the differences between the country and time intercepts Monte Carlo results and the country intercepts only might be because GDP has been more consistently trending up in the OECD countries than in the developing countries in the sample. The average growth rate of income per capita in the OECD was $2.9 \%$ with a standard deviation of $2.9 \%$ while in the non-OECD it was $1.9 \%$ with a standard deviation of $6.6 \%$.

It might be suggested that the global model's failure is due to there being different EKCs in different regions - i.e. different slope parameter estimates and not due to omitted variables. This might explain why the random effects estimator is consistent for the OECD countries as a group (though it is still inconsistent for the non-OECD countries group). A Monte Carlo analysis of this hypothesis uses the parameter estimates from the two subsamples to generate the data set and then fixed and random effects global regressions are estimated using the joint dataset. The median Hausman statistic is 7.4994 which is significant at $2.35 \%$. Note that though the country and time effects used in the simulated data in each subsample are relatively uncorrelated with GDP in that subsample, there is a correlation in the dataset as a whole.

\section{Individual Country EKC Estimates}

The results in the previous section show that no simple global EKC exists. However, the division between OECD and non-OECD subsamples is essentially arbitrary and as shown by, for example, the presence of severe serial correlation, these subsamples are still far too pooled. In this section we examine the adequacy of different EKC models in each individual country as an explanation of emissions in those countries. In addition we can throw further light on the reasons why the global EKC is inadequate.

For each country we estimated two specifications for the determination of per capita emissions: one quadratic in per capita income, the other quadratic in the logarithms of per capita income. A linear time trend was also included in both cases. At face value the results were very mixed, with no obvious patterns emerging in relation to the level of per capita income, geographical location etc.

Table 5. summarizes the results for the 20 countries for which the EKC hypothesis could be strongly supported - the coefficients of the two income variables are correctly signed and significant in both specifications. In 14 countries the time trend is significant in both specifications, and in 11 of these the coefficient on this variable is negative. A positive intercept in the levels specification implies that 
there are emissions of sulfur when no economic activity occurs and is therefore ruled out on theoretical grounds. On the other hand, a negative intercept is possible. At very low levels of income no coal or oil is used and no metal smelting is carried out. Only after a minimum threshold level of income is exceeded might these activities take off. Therefore emissions for a range of extremely low incomes can be approximated by a negative intercept. The only positive levels intercept reported in Table 5 . is not significantly different from zero.

For the 15 countries in Table 6. the results of one of the two specifications support the EKC hypothesis ( 8 of the logarithmic models and 7 of the levels models) while the results using the other specification do not. For 10 of these countries the corresponding turning point is outside the sample range for per capita income. As in Table 5., turning points outside the sample occur for both OECD and non-OECD countries. For 5 countries the levels intercept is positive and significant.

Table 7. lists the 24 countries for which the EKC hypothesis is unequivocally rejected, in that the income coefficients are incorrectly signed in both the levels and logarithms specifications. In 14 cases both specifications involve significant coefficients on income terms. The direction of the time trends is mixed - 8 positive, 10 negative.

These tables do not account for 15 countries where the income coefficients were correctly signed in one or both specifications, but were not, where correctly signed, significant. This group included 4 OECD countries - Austria, Australia, Belgium and Denmark.

The Durbin Watson statistics on the whole showed no autocorrelation or moderate serial correlation. In only one country was the cointegration hypothesis rejected. So while the EKC model provides an adequate explanation of the data in most cases the great variation in parameter estimates suggests that the results are not very meaningful.

The results for individual country regressions can be summarized in the joint distribution of the regression parameters - that is the distribution of the four regression parameters when the 74 countries are treated as observations. Initially we planned to test whether the parameters in each country's regression all came from the same distribution and therefore whether a single regression model was valid. However, we soon realized that there were very strong correlations between the four parameters as shown in Table 8. This meant that looking at histograms for individual parameters makes little sense. In fact the correlations between the constant and the two GDP parameters are close to 1 or -1 . The trend parameter is not closely correlated with the others. The larger the constant is, the greater in absolute value are both the GDP parameters. The absolute values of the two GDP coefficients also covary strongly and positively. These correlations are a similar phenomenon to the inconsistency of the random effects models discussed in the previous section. In this case, though, the correlation is between the intercepts and the coefficients of the GDP variables 
while in the previous section the relevant correlation was between the intercepts and the GDP variables themselves. Most of the EKC effect is taken up by the individual country means and the GDP parameters in the individual country regressions then adjust to cope with these different intercepts. Basic differences between countries are much more important in explaining the EKC than is growth within countries. We also tested the goodness of fit of the 74 regressions versus the global model with a linear time trend and fixed country effects - a test of variation in the slope parameters but not the intercepts. The test statistic is distributed as $\mathrm{F}(219,296)$ and has a value of 17.59741 which is significant at any level (i.e. 0.0000) rejecting the null that the slopes are the same in the global model and the individual country regressions.

\section{Conclusions}

Our results show that estimating an EKC using data for only the OECD countries, as has often been the case, leads to estimates where the turning point is biased downwards relative to emissions reduction possibilities suggested by the EKC estimated using data for the World as a whole. This high global turning point suggests that trade effects could be important. OECD countries have higher emissions reduction possibilities because they can outsource dirty production to the rest of the World through trade specialization. The estimated turning points in individual countries (Tables 5 and 6) are often even lower. Our analysis was aimed at finding purely statistical evidence for or against this proposition. This appears to be due to the omission of two classes of variables: a) serially correlated, integrated, and/or trending variables global variables that correlate with the more consistent economic growth seen in OECD countries b) variables that differ between countries whose means in each country are correlated with mean GDP in those countries. Some of the latter class of variable may also be time dependent. As shown by the Monte Carlo analysis, this latter class of variables seems most important in explaining the relatively lower turning point estimated using samples of OECD countries and therefore in explaining the previously reported EKC for sulfur. Global macro-economic trends or shocks do seem less important. The results do not support the notion that the oil crises of the 1970s are important in explaining the EKC relationship.

We emphasize, that the solution to these problems is not just the use of more widely representative databases such as the ASL database. The tests reported in the paper show that this global model is fundamentally misspecified.

Though the econometrics in this paper provide a number of insights into the nature of the relationship between sulfur emissions and income, our point can also be made by just graphing the data for pairs of economies at similar income levels (Figure 3). Australia and the United Kingdom have similar levels of income and saw a similar increase in income per capita from 1960 to 1990. However, their resource endowments and the changes in their economic structure over time are very different. In the figure we see a steep decline in British emissions and slight increase in Australian emissions. The 
difference in total emissions would be even more striking due to relatively rapid population growth in Australia. Differences between countries seem more important than growth within countries in generating the EKC phenomenon. As we argued in our 1996 paper (Stern et al., 1996):

"We believe that a more fruitful approach to the analysis of the relationship between economic growth and environmental impact would be the examination of the historical experience of individual countries, using econometric and also qualitative historical analysis. " (1159). 


\section{Appendix: Data Sources}

Sulfur Emissions ASL and Associates (1997).

GDP GDP in real 1990 international dollars from the Penn World Table. Data available for 19601990 for most countries. Missing data extrapolated using growth rates of GDP in constant domestic prices from International Financial Statistics and other sources.

Population Same sources as GDP.

\section{List of Countries}

OECD

Australia, Austria, Belgium, Canada, Denmark, Finland, France, Greece, Ireland, Italy, Japan, Luxembourg, Netherlands, Norway, New Zealand, Portugal, Spain, Sweden, Switzerland, Turkey, U.K., U.S.A., West. Germany

\section{Non-OECD}

Algeria, Argentina, Barbados, Bolivia, Brazil, Chile, China, Colombia, Cyprus, Czechoslovakia, Egypt, Ghana, Guatemala, Honduras, Hong Kong, India, Indonesia, Iran, Israel, Kenya, Korea, Kuwait, Madagascar, Malaysia, Mexico, Morocco, Mozambique, Myanmar, Namibia, Nicaragua, Nigeria, Peru, Philippines, Romania, South Africa, Saudi Arabia, Singapore, Sri Lanka, Syria, Taiwan, Tanzania, Thailand, Trinidad\&Tobago, Tunisia, Uruguay, U.S.S.R., Venezuela, Yugoslavia, Zaire, Zambia, Zimbabwe 


\section{References}

A.S.L. and Associates (1997) Sulfur Emissions By Country And Year, Report No: DE96014790, US Department of Energy, Washington DC.

Cole M.A., A.J. Rayner, and J.M. Bates (1997) The environmental Kuznets curve: an empirical analysis, Environment and Development Economics 2(4), 401-416.

de Bruyn S. M., J. C. J. M. van den Bergh, and J. B. Opschoor (1998) Economic growth and emissions: reconsidering the empirical basis of environmental Kuznets curves, Ecological Economics, special issue on EKC.

de Bruyn S. M. (1997) Explaining the environmental Kuznets curve: structural change and international agreements in reducing sulphur emissions, Environment and Development Economics 2(4), 485-503.

Dignon J. and S. Hameed (1989) Global emissions of nitrogen and sulfur oxides from 1860 to 1980, Journal of the Air Pollution Control Association (JAPCA) 39, 180-186.

Dijkgraaf E. and H. R. J. Vollebergh (1998) Growth and/or (?) Environment: Is There a Kuznets Curve for Carbon Emissions?, Paper presented at the 2nd biennial meeting of the European Society for Ecological Economics, Geneva, 4-7th March.

Engle, R. E. and C. W. J. Granger (1987) Cointegration and error-correction: representation, estimation, and testing, Econometrica 55, 251-276.

Grossman G. M. and A. B. Krueger (1991) Environmental Impacts of a North American Free Trade Agreement, National Bureau of Economic Research Working Paper 3914, NBER, Cambridge MA.

Grossman G. M. and A. B. Krueger (1995) Economic growth and the environment, Quarterly Journal of Economics 112, 353-378.

Hameed S. and J. Dignon (1992) Global emissions of nitrogen and sulfur oxides in fossil fuel combustion 1970-1986, Journal of the Air and Waste Management Association 42, 159-163.

Hausman J. A. (1978) Specification tests in econometrics, Econometrica 46, 1251-1271.

Houghton J. T., L. G. Meira Filho, B. A. Callander, N. Harris, A. Kattenberg, and K. Maskell (eds.) Climate Change 1995: The Science of Climate Change, Cambridge University Press, Cambridge (1996).

Hsiao C. (1986) Analysis of Panel Data, Cambridge University Press, Cambridge.

IMF (various issues) International Financial Statistics, International Monetary Fund, Washington, DC.

Kato N. (1996) Analysis of structure of energy consumption and dynamics of emission of atmospheric species related to the global environmental change (SOx, NOx, and $\mathrm{CO} 2$ ) in Asia, Atmospheric Environment 30, 757-785.

Kaufmann R. K. and D. I. Stern (1997) Evidence for human influence on climate from hemispheric temperature relations, Nature 388, 39-44. 
Kaufmann R. K., B. Davidsdottir, S. Garnham, and P. Pauly (1998) The determinants of atmospheric $\mathrm{SO}_{2}$ concentrations: reconsidering the environmental Kuznets curve, Ecological Economics, special issue on EKC.

Lopez R. (1994) The environment as a factor of production: the effects of economic growth and trade liberalization, Journal of Environmental Economics and Management 27, 163-184.

Mitchell J. F. B., T. C. Johns, J. M. Gregory, and S. F. B. Tett (1995) Climate response to increasing levels of greenhouse gases and sulphate aerosols, Nature 376, 501-504.

Moomaw W. R. and G. C. Unruh (1997) Are environmental Kuznets curves misleading us? The case of CO2 emissions, Environment and Development Economics 2(4), 451-463.

OECD (1994) OECD Environmental Indicators, Organisation for Economic Cooperation and Development, Paris.

Mundlak Y. (1978) On the pooling of time series and cross section data, Econometrica 46, 6985.

Panayotou T. (1993) Empirical Tests and Policy Analysis of Environmental Degradation at Different Stages of Economic Development, Working Paper WP238, Technology and Employment Programme, International Labour Office, Geneva.

Panayotou T. (1995) Environmental degradation at different stages of economic development, in: I. Ahmed and J. A. Doeleman (eds.) Beyond Rio: The Environmental Crisis and Sustainable Livelihoods in the Third World, MacMillan, London.

Panayotou T. (1997) Demystifying the environmental Kuznets curve: turning a black box into a policy tool , Environment and Development Economics 2(4), 465-484.

Pezzey J. C. V. (1989) Economic Analysis of Sustainable Growth and Sustainable Development, Environment Department Working Paper No. 15, The World Bank, Washington DC.

Selden T. M. and D. Song (1994) Environmental quality and development: Is there a Kuznets curve for air pollution? Journal of Environmental Economics and Environmental Management 27, 147-162.

Shafik N. (1994) Economic development and environmental quality: an econometric analysis, Oxford Economic Papers 46, 757-773.

Shafik N. and S. Bandyopadhyay (1992) Economic Growth and Environmental Quality: Time Series and Cross-Country Evidence, Background Paper for the World Development Report 1992, The World Bank, Washington DC.

Shukla V. and K. Parikh (1992) The environmental consequences of urban growth: cross-national perspectives on economic development, air pollution, and city size, Urban Geography 12, 422449.

Stern D. I. (1998) Progress on the environmental Kuznets curve? Environment and Development Economics 3(2). 
Stern D. I., M. S. Common, and E. B. Barbier (1996) Economic growth and environmental degradation: the environmental Kuznets curve and sustainable development, World Development. 24, 1151-1160.

Stern D. I. and R. K. Kaufmann (1996) Estimates of Global Anthropogenic Sulfate Emissions 1860-1993, Center for Energy and Environmental Studies Working Paper 9602. Boston University. (http://cres.anu.edu.au/ dstern/CEES_WP/9602.ps).

Summers R. and A. Heston (1991) The Penn World Table (Mark 5): An expanded set of international comparisons, 1950-1988. Quarterly Journal of Economics 106, 1-41.

Torras M. and J. K. Boyce (1996) Income, inequality, and pollution: a reassessment of the environmental Kuznets curve, Ecological Economics, special issue on EKC.

United States EPA (1995) National Air Pollutant Emissions Trends 1900-1994, US Environmental Protection Agency, Office of Air Quality Planning and Standards, Research Triangle Park NC.

Unruh G. C. and W. R. Moomaw (1998) An alternative analysis of apparent EKC-type transitions, Ecological Economics, special issue on EKC.

Vincent J. R. (1997) Testing for environmental Kuznets curves within a developing country, Environment and Development Economics 2(4), 417-431. 
Table 1 Sulfur EKC Studies

\begin{tabular}{|c|c|c|c|c|c|c|c|}
\hline Authors & $\begin{array}{l}\text { Turning } \\
\text { Point }\end{array}$ & $\begin{array}{l}\text { Emis. or } \\
\text { Concs. }\end{array}$ & PPP & Additional Variables & $\begin{array}{l}\text { Data } \\
\text { Source for } \\
\text { Sulfur }\end{array}$ & $\begin{array}{l}\text { Time } \\
\text { Period }\end{array}$ & Countries/cities \\
\hline Cole et al., 1997 & $\$ 6,900$ & Emis. & Yes & $\begin{array}{l}\text { Country dummy, } \\
\text { technology level }\end{array}$ & OECD & $1970-92$ & 11 OECD countri \\
\hline $\begin{array}{l}\text { Grossman and } \\
\text { Krueger, } 1991\end{array}$ & $\begin{array}{l}\$ 4,000- \\
5,000\end{array}$ & Concs. & No & $\begin{array}{l}\text { Locational dummies, } \\
\text { population density, } \\
\text { trend }\end{array}$ & GEMS & $\begin{array}{l}\text { 1977, ' } 82, \\
\text { '88 }\end{array}$ & $\begin{array}{l}\text { Up to } 52 \text { cities } \\
\text { in up to } 32 \\
\text { countries }\end{array}$ \\
\hline $\begin{array}{l}\text { Kaufmann et } \\
\text { al., } 1998\end{array}$ & $\$ 12346$ & Concs. & Yes & $\begin{array}{l}\text { GDP/Area, } \\
\text { exports/GDP }\end{array}$ & $\mathrm{UN}$ & 1974-1989 & $\begin{array}{l}13 \text { developed } \\
\text { and } 10 \\
\text { developing } \\
\text { countries }\end{array}$ \\
\hline $\begin{array}{l}\text { Panayotou, } \\
1993,1995\end{array}$ & $\$ 2,894$ & Emis. & No & - & $\begin{array}{l}\text { Own } \\
\text { estimates } \\
\text { from fuel } \\
\text { use data }\end{array}$ & $1987-88$ & $\begin{array}{l}55 \text { developed } \\
\text { and developing } \\
\text { countries }\end{array}$ \\
\hline $\begin{array}{l}\text { Panayotou, } \\
1997\end{array}$ & $\$ 5,000$ & Concs. & No & $\begin{array}{l}\text { Population density, } \\
\text { policy variables }\end{array}$ & GEMS & $1982-84$ & $\begin{array}{l}\text { Cities in } 30 \\
\text { developed and } \\
\text { developing } \\
\text { countries }\end{array}$ \\
\hline $\begin{array}{l}\text { Selden and } \\
\text { Song, } 1994\end{array}$ & $\begin{array}{l}\$ 8,709- \\
8,901\end{array}$ & Emis. & Yes & Population density & $\begin{array}{l}\text { WRI - } \\
\text { primarily } \\
\text { OECD } \\
\text { source }\end{array}$ & $\begin{array}{l}1979-81,82- \\
87\end{array}$ & $\begin{array}{l}22 \text { OECD and } 8 \\
\text { developing } \\
\text { countries }\end{array}$ \\
\hline Shafik, 1994 & $\$ 3,670$ & Concs. & Yes & $\begin{array}{l}\text { Time trend, locational } \\
\text { dummies }\end{array}$ & GEMS & $1972-88$ & $\begin{array}{l}47 \text { Cities in } 31 \\
\text { Countries }\end{array}$ \\
\hline $\begin{array}{l}\text { Torras and } \\
\text { Boyce, } 1996\end{array}$ & $\$ 3,890$ & Concs. & Yes & $\begin{array}{l}\text { Income inequality, } \\
\text { literacy, political and } \\
\text { civil rights, urbanisation, } \\
\text { locational dummies }\end{array}$ & GEMS & $1977-91$ & $\begin{array}{l}\text { Unknown } \\
\text { number of cities } \\
\text { in } 42 \text { countries }\end{array}$ \\
\hline This study & $\$ 78703$ & Emis. & Yes & Time and country effects & ASL & $1960-1990$ & $\begin{array}{l}74 \text { developed } \\
\text { and developing } \\
\text { countries }\end{array}$ \\
\hline
\end{tabular}


Table 2. Regression Results

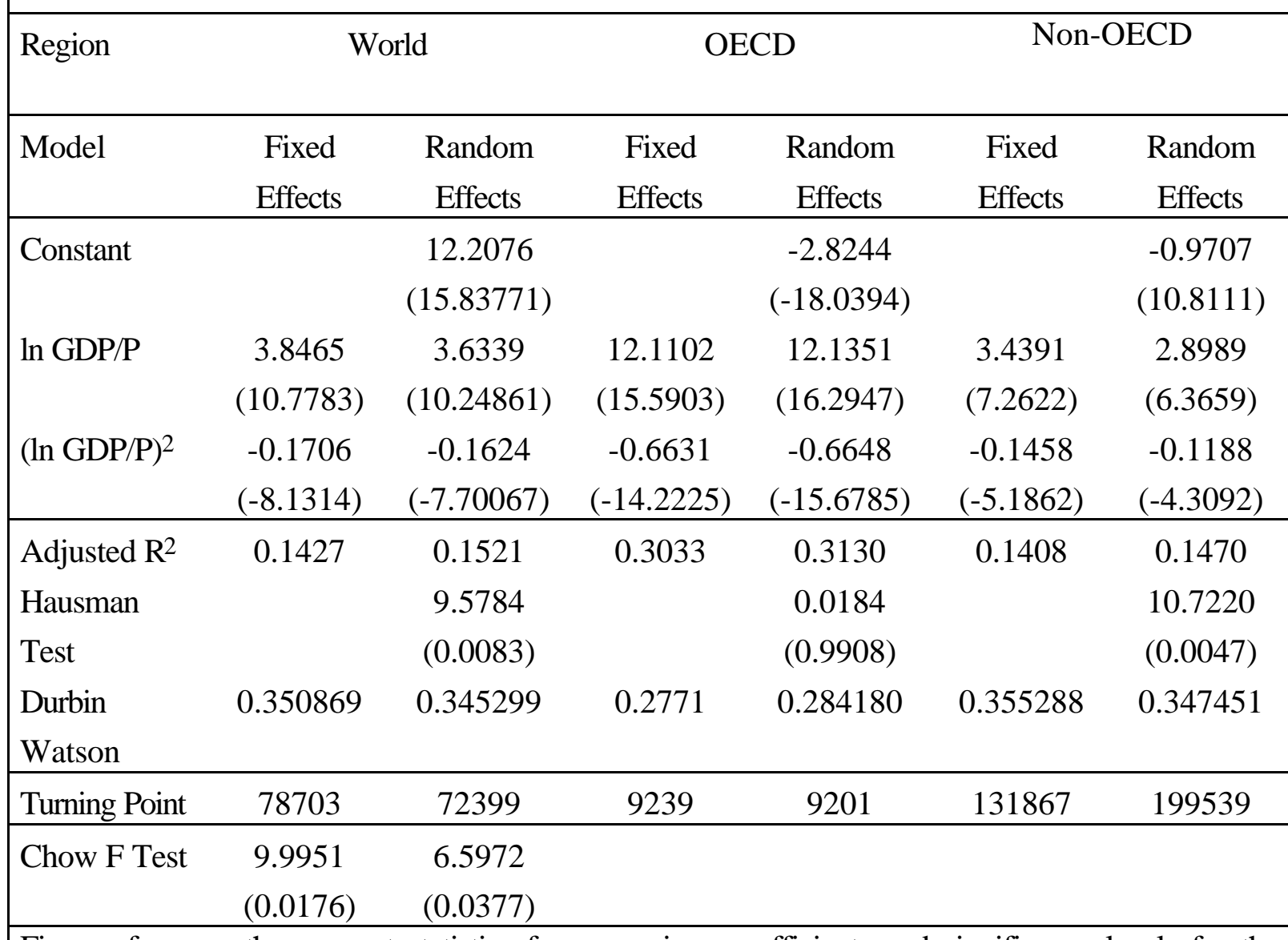

Figures for parentheses are $t$ statistics for regressions coefficients and significance levels for the Hausman. Turning points in real 1990 purchasing power parity US dollars. 


\begin{tabular}{|lccc|}
\hline \multicolumn{4}{|c|}{ Table 3. First Differences Regression Results } \\
\hline Region & World & OECD & Non-OECD \\
& & & \\
\hline Constant & -0.0313 & -0.0160 & -0.0336 \\
& $(-1.7291)$ & $(-0.3567)$ & $(1.6123)$ \\
ln GDP/P & 8.5129 & 10.3325 & 8.3778 \\
& $(3.9552)$ & $(0.8092)$ & $(3.6877)$ \\
$($ ln GDP/P) & -0.4232 & -0.5470 & -0.4129 \\
& $(-3.1474)$ & $(-0.8092)$ & $(-2.8735)$ \\
\hline Adjusted R & 0.0200 & -0.0013 & 0.0290 \\
Durbin & 2.9691 & 2.9992 & 2.9537 \\
Watson & 23343 & 12652 & 25453 \\
\hline Turning Point & & & \\
\hline Figures for parentheses & are t statistics for regressions coefficients. Turning & \\
purchasing pownts in real 1990 & \\
\hline
\end{tabular}


Table 4. Monte Carlo Analysis

\begin{tabular}{|c|c|c|c|c|c|c|c|c|}
\hline $\begin{array}{l}\text { Intercept } \\
\text { Treatment }\end{array}$ & \multicolumn{2}{|c|}{ Single Intercept } & \multicolumn{2}{|c|}{$\begin{array}{c}\text { Country Intercepts } \\
\text { Only }\end{array}$} & \multicolumn{2}{|c|}{$\begin{array}{c}\text { Time Intercepts } \\
\text { Only } \\
\end{array}$} & \multicolumn{2}{|c|}{$\begin{array}{c}\text { Country and Time } \\
\text { Intercepts }\end{array}$} \\
\hline Model & $\begin{array}{l}\text { Fixed } \\
\text { Effects }\end{array}$ & $\begin{array}{l}\text { Random } \\
\text { Effects }\end{array}$ & $\begin{array}{l}\text { Fixed } \\
\text { Effects }\end{array}$ & $\begin{array}{l}\text { Random } \\
\text { Effects }\end{array}$ & $\begin{array}{l}\text { Fixed } \\
\text { Effects }\end{array}$ & $\begin{array}{l}\text { Random } \\
\text { Effects }\end{array}$ & $\begin{array}{l}\text { Fixed } \\
\text { Effects }\end{array}$ & $\begin{array}{l}\text { Random } \\
\text { Effects }\end{array}$ \\
\hline Region & & & & & & & & \\
\hline OECD & 68194 & 75575 & 66192 & 78387 & 60353 & 39721 & 60370 & 16768 \\
\hline $\begin{array}{l}\text { Non- } \\
\text { OECD }\end{array}$ & 77872 & 78198 & 77890 & 85261 & 83911 & 81732 & 79951 & 99574 \\
\hline World & 77566 & 78262 & 78126 & 83386 & 79907 & 77292 & 81430 & 76812 \\
\hline
\end{tabular}

Figures are the median of the turning points. All figures in real 1990 purchasing power parity US dollars. 
Table 5. Countries with correctly signed and significant income parameters in both level and logarithm specifications

\begin{tabular}{|c|c|c|c|}
\hline Country & Time Trends $\mathbf{a}$ & $\begin{array}{l}\text { Turning Points } \\
\text { Levels/Logarithms }\end{array}$ & Levels Intercept $\mathrm{c}$ \\
\hline \multicolumn{4}{|l|}{ Non-OECD } \\
\hline Kenya & Both negative & $839 / 833$ & Negative* \\
\hline Madagascar & Both positive & $1273 * / 1422 *$ & Negative* \\
\hline Tanzania & Levels negative & $502 / 507$ & Negative* \\
\hline Tunisia & & $1520 / 1665$ & Positive \\
\hline Zimbabwe & & $1249 / 1238$ & Negative* \\
\hline Barbados & & $9274 * / 6489$ & Negative* \\
\hline Honduras & Both negative & $1401 / 1413$ & Negative* \\
\hline Bolivia & Both negative & $1967 / 2215^{*}$ & Negative* \\
\hline Malaysia & Logarithms positive & $3574 / 2364$ & Negative \\
\hline Philipines & Both negative & $1850 / 1874$ & Negative* \\
\hline Singapore & Both positive & $8480 / 3431$ & Negative* \\
\hline $\begin{array}{l}\text { Sri Lanka } \\
\text { OECD }\end{array}$ & Both positive & $1302 / 1420$ & Negative \\
\hline USA & Both negative & $18561 * / 22326^{*}$ & Negative* \\
\hline Finland & & 10994/10982 & Negative \\
\hline West Germany & Both negative & $13077 / 13723$ & Negative \\
\hline Italy & Both negative & $15292 * / 60943 *$ & Negative* \\
\hline Luxemburg & Both negative & $13995 / 15142$ & Negative* \\
\hline Norway & Both negative & $11325 / 12787$ & Negative* \\
\hline Switzerland & Both negative & $15875 / 15489$ & Negative* \\
\hline New Zealand & Both negative & $10808 / 10535$ & Negative* \\
\hline $\begin{array}{l}\text { a: Where significat } \\
\text { b: * indicates outs } \\
\text { c: * indicates sign }\end{array}$ & $\begin{array}{l}\% \\
\text { aple range } \\
\text { at } 5 \%\end{array}$ & & \\
\hline
\end{tabular}


Table 6. Countries with correctly signed income parameters significant in one specification

\begin{tabular}{|c|c|c|c|c|}
\hline Country & Specification & Trend $^{\mathbf{a}}$ & Turning Point ${ }^{b}$ & $\begin{array}{l}\text { Levels } \\
\text { Intercept }\end{array}$ \\
\hline \multicolumn{5}{|l|}{ Non-OECD } \\
\hline Guatemala & Logarithms & Negative & 257 & Negative* \\
\hline Nicaragua & Logarithms & Negative & 1550 & Positive \\
\hline Trinidad & Logarithms & Negative & 9838 & Negative \\
\hline Colombia & Levels & Positive & $3360 *$ & Positive* \\
\hline Indonesia & Logarithms & Negative & $2186^{*}$ & Negative \\
\hline Korea & Levels & & $7838 *$ & Negative \\
\hline Thailand & Logarithms & Negative & $4941 *$ & Positive \\
\hline Czechoslovakia & Levels & & $4433 *$ & Positive* \\
\hline Romania & Logarithms & Positive & $2281 *$ & Positive* \\
\hline $\begin{array}{l}\text { USSR } \\
\text { OECD }\end{array}$ & Levels & Negative & $9517 *$ & Positive \\
\hline Japan & Levels & Negative & $15521 *$ & Negative* \\
\hline France & Levels & Negative & $28720 *$ & Negative* \\
\hline Spain & Logarithms & Positive & 4412 & Positive* \\
\hline Sweden & Logarithms & Positive & 8404 & Positive* \\
\hline Canada & Levels & Negative & $22067 *$ & Negative* \\
\hline \multicolumn{5}{|c|}{$\begin{array}{l}\text { a: Where significant at } 5 \% \\
\text { b: * indicates outside sample range } \\
\text { c: * indicates significant at } 5 \%\end{array}$} \\
\hline
\end{tabular}


Table 7. Countries with incorrectly signed income parameters in both levels and logarithmic specifications

\begin{tabular}{|c|c|c|}
\hline Country & $\begin{array}{l}\text { Specification with significant } \\
\text { coefficients }\end{array}$ & Trend $^{\mathbf{a}}$ \\
\hline \multicolumn{3}{|l|}{ Non-OECD } \\
\hline Algeria & Both & \\
\hline Egypt & Logarithms & \\
\hline South Africa & & Positive, both \\
\hline Zambia & Levels & Negative, both \\
\hline Mexico & Both & Positive, both \\
\hline Argentina & & Negative, both \\
\hline \multicolumn{3}{|l|}{ Brazil } \\
\hline Chile & Both & Positive, both \\
\hline Peru & & Negative, both \\
\hline Venezuela & & Negative, both \\
\hline Hong Kong & Both & \\
\hline India & Both & Positive, both \\
\hline Iran & & Negative, both \\
\hline Kuwait & Both & \\
\hline Mynamar & Both & Negative, both \\
\hline Syria & Both & Positive, both \\
\hline Cyprus & Both & Negative, both \\
\hline Turkey & Both & Positive, both \\
\hline $\begin{array}{l}\text { Yugoslavia } \\
\text { OECD }\end{array}$ & Both & Positive, both \\
\hline Greece & Both & Positive, both \\
\hline \multicolumn{3}{|l|}{ Ireland } \\
\hline The Netherlands & Both & Negative, both \\
\hline Portugal & Both & Negative, both \\
\hline United Kingdom & & Negative, both \\
\hline
\end{tabular}


Table 8. Correlations between Parameters in Individual Country Regressions

\begin{tabular}{|l|llll|}
\hline & Constant & $\ln$ GDP/P & $(\ln$ GDP/P) & Trend \\
\hline Constant & 1 & -0.9911 & 0.9620 & -0.0176 \\
$\ln$ GDP/P & -0.9911 & 1 & -0.9897 & 0.0261 \\
$(\ln \text { GDP/P })^{2}$ & 0.9620 & -0.9897 & 1 & -0.0504 \\
Trend & -0.0176 & 0.0261 & -0.0504 & 1 \\
\hline
\end{tabular}


Figure 1 Complete Data Set

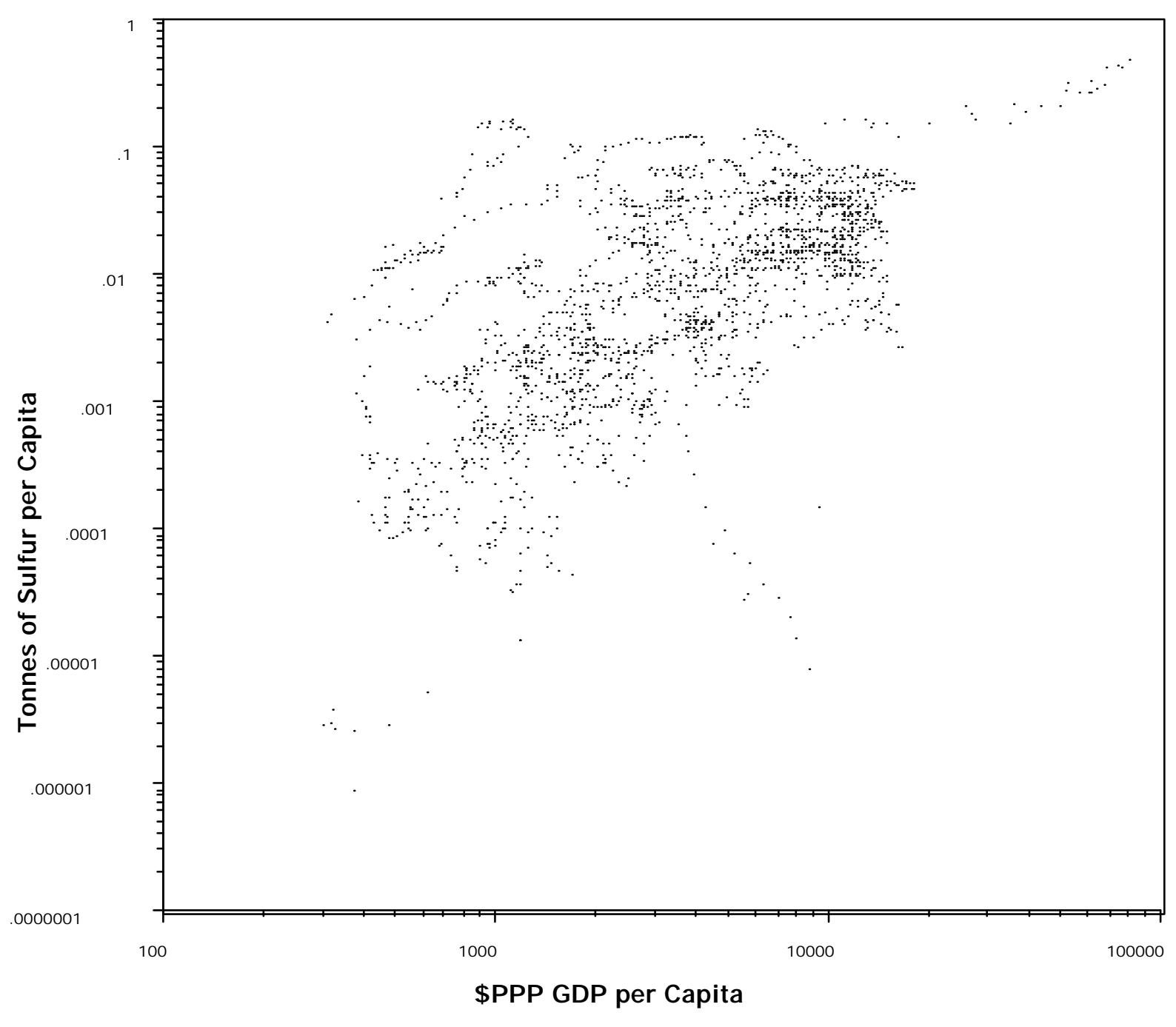


Figure 2. Fixed Time Effects for World, OECD, and non-OECD EKCs

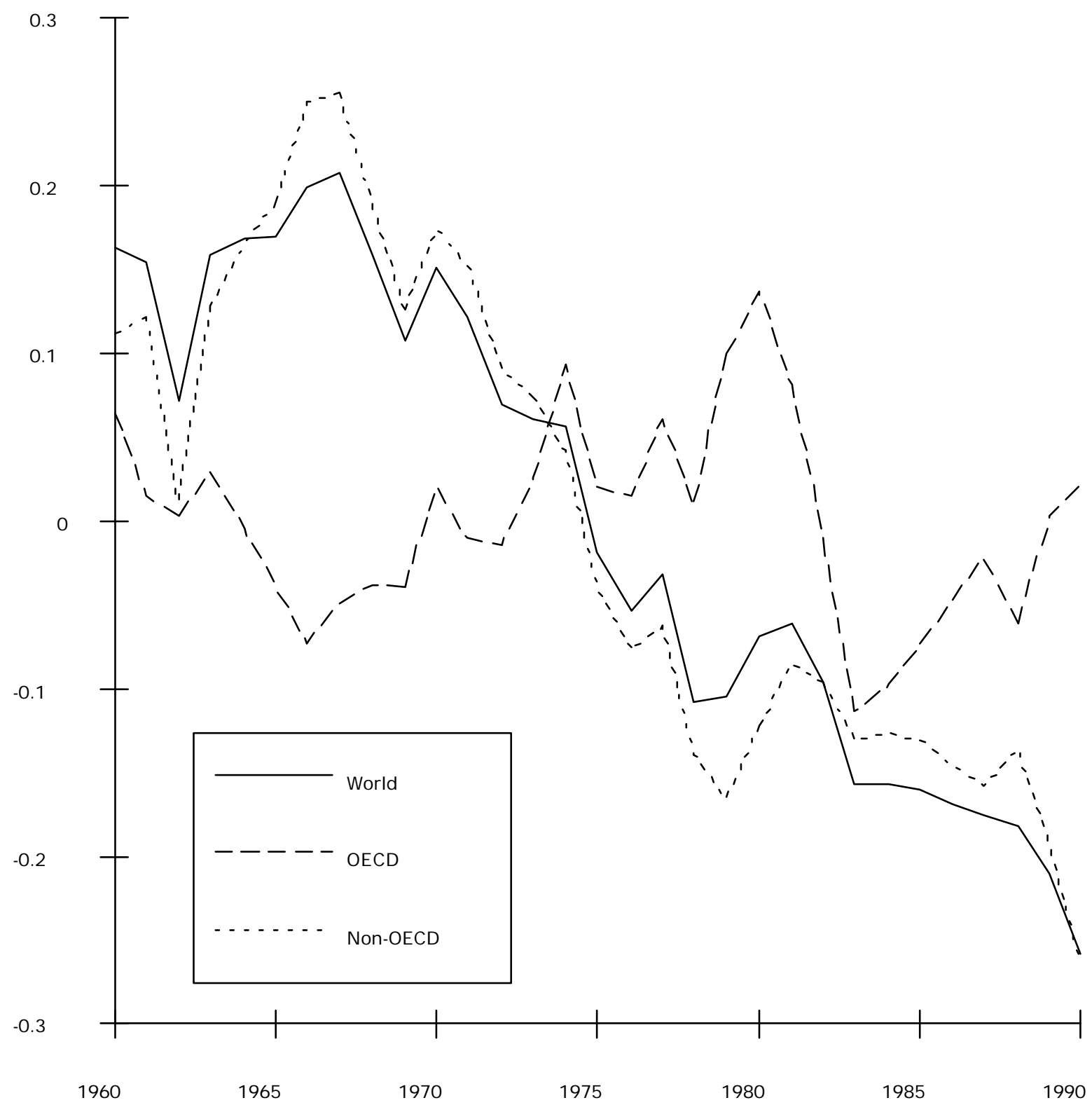


Figure 3. Sulfur Emissions for Australia and United Kingdom

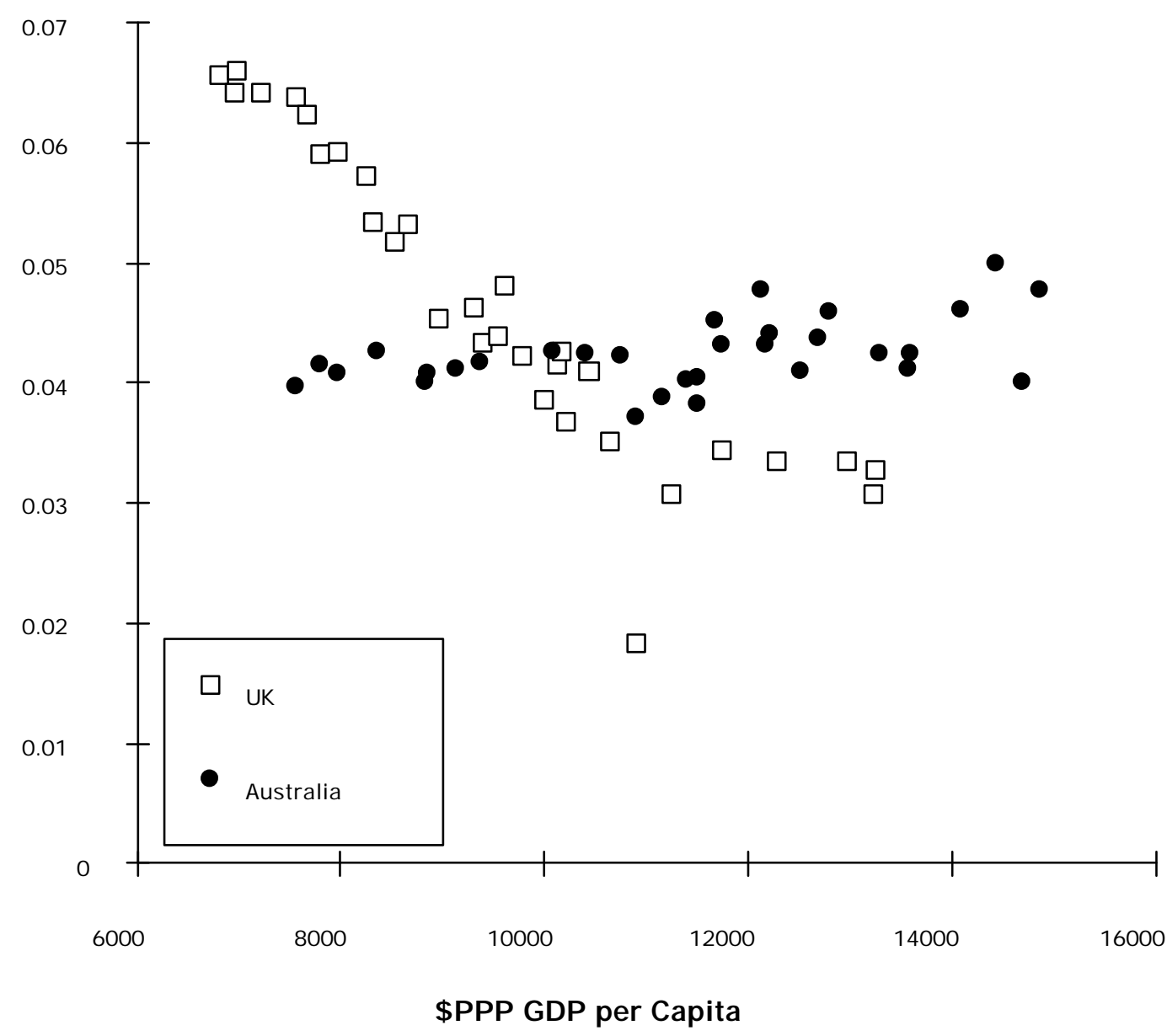

